\title{
PEMIKIRAN POLITIK ISLAM DI INDONESIA: DARI FORMALISTIK MENUJU KE SUBSTANTIF
}

\author{
Rachmat Panca Putera \\ IAI Agus Salim \\ rachmatpancaputra9@gmail.com
}

\begin{abstract}
Political thinking about the relationship religion and countries have a problem with the most attractive to moslem community, the relationship between islam and state in indonesia in be indonesian history is a story antagonistic and suspicion each other.Not intimate relationship is mainly, but not wholly, caused by the views on the founder of the country most of it muslims about was about to be taken kemanakah country newly independent.One of the most important items in a difference of opinion on wased this country inclined to islam, or nationalist muslim religion not determinant certain system for muslims.Political islam in indonesia can not be separated from the dynamics of thought and the renewal of a movement. Among in general divided into two groups. The first group were convinced that the islamic state of as a model of government will guarantee the teachings of islam implemented in the community. The second group refuse formalism religion in state affairs, the opposite of them focused on the importance of grow and to create and integrity of the religious society of the people.
\end{abstract}

Key words: Islamic Politics, Synergy

\begin{abstract}
Abstrak
Pemikiran politik tentang hubungan agama dan negara telah menjadi persoalan yang paling banyak diminati oleh masyarakat muslim, hubungan antara Islam dan negara di Indonesia pada sebagaian besar babakan sejarahnya adalah kisah antagonis dan kecurigaan satu sama lain. Hubungan yang tidak mesra ini terutama, tapi tidak seluruhnya, disebabkan oleh perbedaan pandangan pada pendiri Republik Indonesia yang sebagian besarnya umat Muslim mengenai hendak dibawa kemanakah negara Indonesia yang baru merdeka. Salah satu butir terpenting dalam perbedaan pendapat di atas itu adalah apakah negara ini bercorak "Islam" atau "nasionalis"Islam sebagai agama tidak menentukan system peerintahan tertentu bagi umat Islam. Politik Islam di Indonesia tidak lepas dari dinamika pemikiran dan gerakan pembaharuan. Kalangan muslim secara umum terbagi dalam dua kelompok. Kelompok pertama meyakini bahwa negara Islam sebagai model pemerintahan akan menjamin terlaksana ajaran Islam di masyarakat. Kelompok kedua menolak formalism agama dalam urusan kenegaraan, sebaliknya mereka memfokuskan pada pentingnya menumbuhkan dan membina masyarakat religius dan integritas bangsa.
\end{abstract}

Kata kunci: Politik Islam, Sinergi

\section{Pendahuluan}

Pemikiran politik tentang hubungan agama dan negara telah menjadi persoalan yang paling banyak diminati oleh masyarakat muslim, terutama pada abad 19 hingga abad 21. Wacana hubungan agama dan negara selalu menjadi hal yang menarik bagi para pemikir politik Islam.

Secara global di dunia Islam terdapat tiga aliran tentang hubungan Islam dan ketatanegaraan: Pertama, aliran pertama berpendapat bahwa Islam adalah agama yang lengkap, yang mencakup pengaturan bagi semua aspek manusia 
termasuk ketatanegaraan. Kedua, aliran kedua ini berpendapat bahwa Islam adalah agama dalam pengertian Barat, Islam tidak ada hubungannya dengan ketatanegaraan karena Nabi Muhammad SAW bukanlah sebagai kepala negara melainkan hanya seorang utusan Allah SWT. Ketiga, aliran ketiga ini berpendapat bahwa aliran ini menolak Islam adalah agama yang lengkap, namun juga menolak pendapat bahwa Islam tidak ada hubungan sama sekali dengan ketatanegaraan, aliran ini mengatakan bahwa dalam Islam terdapat seperangkat tata nilai etika bagi kehidupan bernegara. ${ }^{1}$

Indonesia merupakan negara yang mayoritas masyarakatnya beragama Islam, keterlibatan agama dalam merespon berbagai masalah kehidupan sosial semakin jelas dan signifikan, termasuk dalam menempatkan hubungan yang memungkinkan antara Islam dan negara. Karena masalah ini seringkali menjadi problem yang bersifat mendasar. Oleh karenanya tidaklah mengherankan kalau pemikiran tentang Islam dan negara ini sudah menjadi diskusi dan perdebatan ulama sejak tempo dulu hubungan antara Islam dan negara di Indonesia pada sebagaian besar babakan sejarahnya adalah kisah antagonis dan kecurigaan satu sama lain. Hubungan yang tidak mesra ini terutama, tapi tidak seluruhnya, disebabkan oleh perbedaan pandangan pada pendiri Republik Indonesia yang sebagian besarnya umat Muslim mengenai hendak dibawa kemanakah negara Indonesia yang baru merdeka. Salah satu butir terpenting dalam perbedaan pendapat di atas itu adalah apakah negara ini bercorak "Islam" atau "nasionalis". ${ }^{2}$ Konstruk kenegaraan pertama mengharuskan Islam harus diakui dan diterima sebagai dasar ideologi negara. Sementara itu konstruk kenegaraan kedua mendesak agar negara ini didasarkan pada Pancasila sebagai dasar ideologi negara

Munawir Sjadzali berpendapat bahwa Islam dan negara tidak berkaitan, piagam Madinah yang dianggap sebagai Konstitusi oleh umat Islam tidak menyebutkan agama negara. ${ }^{3}$ Menurutnya Piagam Madinah hanya sebagai landasan kehidupan bermasyarakat bukan untuk membentuk sebuah negara, nabi Muhammad SAW pun tidak menjelaskan yang dibentuk di Madinah adalah sebuah negara.

Muhammad Tahir Azhari dengan gagasan pembaharuan ideologi negara. Ia berpendapat, "dari tinjauan yang lebih prinsipil, konsep negara Islam adalah sebuah distorsi hubungan proporsional antara agama dan negara. Negara adalah salah satu segi kehidupan duniawi yang dimensinya adalah rasional dan

${ }^{1}$ Munawir Sjadzali, Islam dan Tatanegara: Ajaran Sejarah dan Pemikiran, edisi revisi (Jakarta: UI Press, 2003), h. 1

2Bahtiar Effendy, Islam dan Negara: Transformasi Gagasan dan Praktik Politik Islamdi Indonesia (Jakarta: Democracy, 2011) h 5

${ }^{3}$ Munawir Sjadzali , . h. 16. 
kolektif, sedangkan agama adalah aspek kehidupan yang dimensinya adalah spiritual dan pribadi". ${ }^{4}$

Bahtiar Effendy juga mengungkapkan bahwa di Indonesia terjadi antagonisme politik antara Islam dan negara yang sebagaian besar disebabkan oleh idealisme dan aktivisme Islam politik yang bercorak legalistik dan formalistik. ${ }^{5}$ dealisme dan aktivisme para politisi Muslim dicirikan oleh formalisme dan legalisme mengakibatkan berlangsungnya hubungan politik yang tidak mudah antara Islam dan negara di Indonesia. Ia berargumentasi dengan menggunakan gagasan transformasi intelektual dapat merubah sikap negara terhadap politik Islam itu sendiri.

\section{Pembahasan}

\section{Konsep Negara dalam Islam}

Agama dan negara, adalah dua buah intitusi yang sangat penting bagi masyarakat khususnya yang ada dalam wilayah keduanya. ${ }^{6}$ Agama sebagai sumber etika moral mempunyai kedudukan yang sangat vital karena berkaitan erat dengan perilaku seseorang dalam interaksi sosial kehidupannya. Dalam hal ini agama dijadikan sebagai alat ukur atau pembenaran dalam setiap langkah kehidupan, baik itu interaksi terhadap sesama maupun kepada sumber agama itu sendiri, pada sisi lain negara merupakan sebuah bangunan yang mencakup seluruh aturan mengenai tata kemasyarakatan berlaku dan mempunyai kewenangan memaksa bagi setiap masyarakat. Bisa saja aturan yang dibuat oleh negara sejalan dengan agama, tetapi bisa juga apa yang ditetapkan berlawanan dengan agama.

Konsep negara dalam Islam termasuk wilayah ijtihad umat Islam. Oleh karena itu, masalah negara merupakan urusan duniawi yang bersifat umum. Dalam menyusun teori politik mengenai konsep negara, hal yang ditekankan bukanlah struktur "negara Islam", melainkan substruktur dan tujuannya. Hal ini dikarenakan struktur negara termasuk wilayah ijtihad kaum Muslim sehingga bisa berubah. Adapun substruktur dan tujuannyaa tetap menyangkut prinsipprinsip bernegara secara Islami.

Al-Quran mengandung nilai-nilai dan ajaran yang bersifat etis mengenai aktivitas sosial-politik umat manusia. Ajarannya ini mencangkup prinsipprinsip tentang keadilan, persamaan, persaudaraan, musyawarah, dan lainlain.7Islam adalah agama universal, agama yang membawa misi rahmatan lil alamin. Islam juga memberikan konsep kepada manusia

${ }^{4}$ Muhammad Tahir Azhari, Negara Hukum : Suatu Study Tentang Prrinsip-PrinsupnyaDilihat Dari Segi Hukum Isam, Implementasinya Pada Periode Negara Madinah dan Masa Kini, (Jakarta: Bulan Bintang, 2003), h. 33.

${ }^{5}$ Bahtiar Effendy, Islam dan Negara di Indonesia (Jakarta: PT Temprin, 1995) h 146

6 John L. Esposito, Islam and Politics, terj. H.M. Josoef Sou'yb, Islam dan Politik, (Jakarta: PT. Bulan Bintang, 2000), h. 38.

7Jubair Situmorang, Model Pemikiran dan Penelitian Politik Islam, (Bandung: Pustaka Setia, 2014), h 55 
mengenai persoalan yang berkaitan dengan urusan duniawi, seperti cara mengatur perekonomian, penegakan hukum, konsep politik, dan sebagainya. Salah satu bukti tercatat dalam sejarah, ketika Nabi hijrah ke kota Madinah, beliau mampu menyatukan masyarakat yang majemuk yang terdiri atas berbagai agama dan peradaban yang berbeda dalam satu tatanan masyarakat madani.

Menurut pandangan Ibnu Taimiyah, negara dan agama saling berkaitan menjadi satu. Tanpa kekuasaan negara yang bersifat memaksa, agama berada dalam bahaya. Tanpa disiplin hukum wahyu, negara pasti menjadi sebuah organisasi yang tirani. ${ }^{8}$

Politik Islam dalam hal ini yaitu hubungan agama dan negara merupakan persoalan yang banyak menimbulkan perdebatan yang terus berkepanjangan dikalangan para ahli. ${ }^{9} \mathrm{Hal}$ ini disebabkan oleh perbedaan pandangan dalam menerjemahkan agama sebagai bagian dari negara atau negara merupakan bagian dari dogma agama. Bahkan dikatakan bahwa persoalan yang telah memicu konflik intelektual untuk pertama kalinya dalam kehidupan umat Islam adalah berkait dengan masalah hubungan agama dengan negara. ${ }^{10}$

Islam setidaknya meliputi dua aspek pokok yaitu agama dan masyarakat (politik).11Akan tetapi untuk mengartikulasikan dua aspek tersebut dalam kehidupan nyata merupakan suatu problem tersendiri. Umat Islam pada umumnya mempercayai watak holistik Islam. Dalam persepsi mereka, Islam sebagai instrumen Ilahiyah untuk memahami dunia, seringkali lebih dari sekedar agama. Banyak dari mereka malah menyatakan bahwa Islam juga dapat dipandang sebagai agama negara. ${ }^{12}$

Negara dalam Islam bisa diterjemahkan dengan berbagai cara. Perbedaan ini bukan saja disebabkan oleh faktor sosio-budaya-historis, tetapi bersumber juga dari aspek teologis-doktrinal. Menurut Karim, walaupun Islam mempunyai konsep khalifah, daulah, hukumah tetapi alQurean belum menjelaskan secara rinci bentuk dan konsepsi sebuah negara. ${ }^{13}$

Menurut Din Syamsuddin, secara umum ada tiga bentuk paradigma tentang hubungan agama dan negara.Paradigma ini memecahkan masalah dikotomi dengan mengajukan konsep bersatunya agama dan negara. Agama dan negara dalam hal ini tidak dapat dipisahkan. Wilayah agama juga

8Jubair Situmorang, Model Pemikiran dan Penelitian Politik Islam, h 50

${ }^{9}$ Dede Rosyada, Pendidikan Kewargaan (Civic Education): Demokrasi, HakAsasi Manusia dan Masyarakat Madani, (Jakarta: ICCE UIN Syarif Hidayatullah, 2000), h. 58.

${ }^{10}$ M. Rusli Karim, Negara dan Peminggiran Islam Politik, (Yogyakarta: Tiara Wacana, 1999), h

9

11Deliar Noer, Gerakan Modern Islam di Indonesia 1900-1942, (Jakarta: LP3ES, 1996), h. 1.

${ }^{12}$ Ahmad Syafi" i Maarif, Islam dan Masalah Kenegaraan Studi tentang Percaturandalam Konstituante, (Jakarta: LP3ES, 1996), h. 15.

${ }^{13}$ M. Rusli Karim, Op Cit h 1 
meliputi politik atau negara. Oleh karena itu, menurut paradigma ini, negara merupakan lembaga politik dan keagamaan sekaligus. ${ }^{14}$ Kelompok ini, memandang syari"eah sebagai totalitas yang kaffah kamilah bagi tatanan kehidupan kemasyarakatan dan kemanusiaan. Sementara negara berfungsi untuk menjalankan syari'ah. Implikasinya jelas, dimana aturan kenegaraan harus dijalankan menurut hukum-hukum Tuhan (syari'ah). Ayat-ayat alQur'an yang sering dikumandangkan sebagai legitimasi bagi penerapan hukum Tuhan ini antara lain:

a) Paradigma Integralistik

Paradigma ini memecahkan masalah dikotomi dengan mengajukan konsep bersatunya agama dan negara. Agama dan negara dalam hal ini tidak dapat dipisahkan. Wilayah agama juga meliputi politik atau negara. Oleh karena itu, menurut paradigma ini, negara merupakan lembaga politik dan keagamaan sekaligus.51 Kelompok ini, memandang syari'ah sebagai totalitas yang kaffah kamilah bagi tatanan kehidupan kemasyarakatan dan kemanusiaan. Sementara negara berfungsi untuk menjalankan syarie ah.

Implikasinya jelas, dimana aturan kenegaraan harus dijalankan menurut hukum-hukum Tuhan (syari"ah). Implikasinya jelas, dimana aturan kenegaraan harus dijalankan menurut hukum-hukum Tuhan (syari"ah). Ayat-ayat alQur"an yang sering dikumandangkan sebagai legitimasi bagi penerapan hukum Tuhan. Paradigma ini dianut kelompok syi"eah, yang pemikiran politiknya memandang bahwa negara adalah lembaga keagamaan dan mempunyai fungsi kenabian.hubungan legitimasi keagamaan berasal dari Tuhan dan diturunkan lewat garis keturunan Nabi Muhammad, legitimasi garis berdasarkan pada hukum Allah, dan hal itu hanya dimiliki oleh para keturunan Nabi. ${ }^{15}$

b) Paradigma Simbiotik

Paradigma kedua memandang agama dan negara berhubungan secara simbiotik, yaitu berhubungan erat secara timbal balik dan saling memerlukan. Dalam hal ini, agama memerlukan negara karena dengan negara agama dapat berkembang. Sebaliknya, negara memerlukan agama, karena dengan agama, negara dapat berkembang dalam bimbingan etika dan moral.

Aliran pemikiran ini menyadari, istilah negara (dawlah) tidak dapat ditemukan dalam al-Qur'an. Meskipun terdapat berbagai ungkapan dalam al-Qur'an yang merujuk atau seolah-olah merujuk kepada kekuasaan politik dan otoritas, akan tetapi ungkapan-ungkapan ini hanya bersifat insidental dan tidak ada pengaruhnya bagi teori

${ }^{14}$ M. Din Syamsudin, Usaha Pencarian Konsep Negara dalam Sejarah Pemikiran Politik Islam(Bandung: Pustaka Hidayah, Cet. ke-1, 1999), h. 45-46

15 Din Syamsudin,.. h 46 
politik. Bagi mereka, jelas bahwa "al-Qur'an bukanlah buku tentang ilmu politik. ${ }^{16}$

c) Paradigma Sekuleristik.

Paradigma ketiga ini bersifat sekuralistik. Paradigma ini menolak hubungan integralistik dan simbiotik antara agama dan negara.Dalam konteks Islam, paradigma sekuralistik menolak pendasaran agama pada negara atau menolak determinasi Islam terhadap bentuk tertentu negara. Menurut paradigma ini, Islam hanya mengatur hubungan manusia dengan Tuhan. Sedangkan hal-hal yang berkaitan dengan kehidupan bermasyarakat dan bernegara pengaturannya diserahkan sepenuhnya kepada umat manusia. Masing-masing entitas dari keduanya mempunyai garapan dalam bidangnya sendiri. Sehingga keberadaannya harus dipisahkan dan tidak boleh satu sama lain melakukan intervensi.

Berdasarkan pada pemahaman yang dikotomis ini, maka hukum positif yang berlaku adalah hukum yang benar-benar berasal dari kesepakatan manusia melalui social contract dan tidak ada kaitannya dengan hukum agama (syari"ah). ${ }^{17}$

Salah satu orang yang memprakarsai paradigma ini adalah Ali Abdur Raziq pada tahun 1925 ia menerbitkan sebuah risalah yang berjudul Al-Islam wa Ushul Al-Hukm. Menurutnya pembentukan negara tidak disarankan oleh agama (syari"at) melainkan berdasarkan akal umat.61 Pada zaman Nabi di Madinah dilihat dari sudut apa pun, menurutnya bukanlah persatuan politik. Disana tidak terkandung makna daulah atau pemerintahan, tetap murni persatuan agama yang tidak dicampuri noda-noda politik. Persatuan iman dan pandangan agama bukanlah persatuan daulah dan pandangan kekuasaan. ${ }^{18}$

\section{Agama dan Negara dalam Politik Islam di Indonesia}

Hubungan antara Islam dan politik di Indonesia memiliki tradisi yang amat panjang. Akar-akar genealogisnya dapat ditarik ke belakang hingga akhir abad ke-13 dan awal abad ke-14, ketika Islam seperti dikatakan banyak kalangan pertama kali diperkenalkan dan disebarkan di kepulauan Indonesia. Dalam perjalanan sejarahnya, Islam mengadakan dialog yang bermakana dengan realitas-realitas sosio-kultural dan politik pada tingkat lokal, terlibat dalam politik. Pada kenyataannya malah dapat dikatakan bahwa Islam, sepanjang perkembangannya di Indonesia, telah menjadi

\footnotetext{
2000), h. 60

${ }^{16}$ Din Syamsuddin, Etika dalam Membangun Masyarakat Madani,(Jakarta: Logos Wacana Ilmu,

17Dede Rosyada, et. al., Pendidikan Kewargaan (Civic Education): Demokrasi, HakAsasi Manusia dan Masyarakat Madani, (Jakarta: ICCE UIN Syarif Hidayatullah, 2000), h. 63-64

${ }^{18}$ Ali Abdul Raziq, Al-Islam wa Usul al-Ahkam, Mesir: 1925, dan telah diterjemahkan ke dalam bahasa Indonesia, Islam dan Dasar-Dasar Pemerintahan, (Yogyakarta: Jendela, 2000), h. 85
} 
bagian integral dari sejarah politik di Indonesia. Meskipun begitu tidak semerta-merta bahwa Islam adalah agama politik. ${ }^{19}$

Ekstitensi Islam politik (political Islam) pada masa kemerdekaan dan sampai pada pasca reformasi pernah dianggap sebagai persaingan kekuasaan yang dapat mengusik basis kebangsaan negara. Persepsi tersebut, membawa implikasi terhadap keinginan negara untuk berusaha menghalangi dan melakukan domestikasi terhadap gerak ideologis politik Islam.

Antagonistik politik antara Islam dan negara sebagaian besar disebabkan oleh idealisme dan aktivisme Islam politik yang bercorak legalistik dan formalistik. Hubungan yang tidak mesra ini disebabkan oleh perbedaan pandangan pada pendiri republik ini yang sebagian besarnya Muslim, mengenai hendak dibawa kemanakah negara Indonesia ini apakah negara bercorak Islam atau nasionalis. ${ }^{20}$

Tema-tema politik Islam lebih bergulir pada tataran ideologi dan simbol ketimbang substansi, dan tema- tema Islam pada tataran ideologi dan simbolik mencapai klimaksnya pada perdebatan dalam konstituante pada paruh kedua dasawarsa 1950-an. Paparan historis yang terkesan deskriptif itu, secara tegas menunjukkan bahwa suhu politik yang tertampung dalam majelis konstuante tidak dapat mendinginkan cita- cita idiologis antara golongan Islam dan golongan nasionalis sekuler, yang keduanya memang sudah lama bersitegang.

Upaya untuk menemukan hubungan politik yang pas antara Islam dan negara terus berlanjut pada periode kemerdekaan dan pascarevolusi, lantaran tidak juga kunjung ditemukan, menyebabkan berkembangnya kesaling curigaan yang lebih besar antara Islam dan negara.

Meskipun cita-cita terbinanya hubungan yang mesra dan saling melengkapi antara Islam dan negara, belum sepenuhnya berhasil terwujud, ada beberapa isyarat penting yang mengindikasikan masuknya kembali Islam politik kedalam kehidupan politik negeri ini. Bukti yang memperlihatkan perkembangan baru ini adalah sikap negara yang mulai tampak ramah terhadap Islam, yang ditandai oleh diterapkannya kebijakankebijakan tertentu yang dipandang sejalan dengan kepentingan sosialekonomi, kultural dan politik Islam. buktibukti akomodasi jika dikategorikan secara luas, bisa digolongkan kedalam empat jenis berbeda: (1) akomodasi structural; (2) akomodasi legislatif (3) akomodasi infrastruktual (4) akomodasi kultural. ${ }^{21}$

${ }^{19}$ Bahtiar Effendy, Teologi Baru Politik Islam Pertautan Agama, Negara danDemokrasi, (Yogyakarta: Galang Press, 2001), h. 7

20Ibid, h 22

${ }^{21}$ Bahtiar Effendy, Islam dan Negara di Indonesia (Jakarta: PT Temprin, 1995), h. 345 
Salah satu bentuk akomodasi yang paling mencolok adalah direkrutnya para pemikir dan aktivis Islam politik generasi baru ke dalam lembaga-lembaga eksekutif dan legislatif negara. Sedikitnya ada dua alasan utama dibalik fenomena tersebut : yang pertama bersifat sosiologis, yang kedua bersifat politis.

Akomodasi struktural berkembang dalam jumlah dan substansinya. Tidak hanya lebih banyak aktivis muslim yang direkrut ke dalam mesin birokrasi dan politik, tetapi mereka juga dipromosikan untuk menduduki posisi yang lebih tinggi.

Dalam konteks yang lebih luas, akomodasi kultural negara terhadap Islam bukanlah fenomena yang baru. Hal itu bahkan merupakan diskursus yang masih berlangsung, yang diakibatkan oleh proses akulturasi antara Islam dengan berbagai kekhususan ruang dan waktu Indonesia. Hasil-hasil yang muncul dari perjumpaan kultural itu amat beragam, sebagian besarnya tergantung kepada tingkat kemampuan kelompok-kelompok yang terlibat dalam melakukan proses rekonsiliasi atas keduanya. Tetapi pada umumnya, akomodasi itu mencakup dari yang parsial (sinkretis) sampai yang total (murni)." Mengingat kenyataan bahwa "Islam telah mengembangkan dirinya secara amat cepat, dan secara keseluruhan dengan cara-cara damai, di sebagian besar kepulauan Nusantara," maka tidak berlebihan jika dikatakan bahwa banyak aspek kebudayaan Islam yang sudah lama terakomodasikan.

Formulasi linguistik Pancasila merupakan salah satu indikasi yang secara gamblang membuktikan butir di atas. Jika preposisi gramatikal dan kata sambungnya diabaikan, dapat diperkirakan bahwa sepertiga dari kata dan ungkapan dalam Pancasila terdiri dari idiomidiom Islam. Hal ini termasuk kata-kata seperti "adil," "adab," "rakyat," "hikmah," "musyawarah," dan "wakil." Penamaan beberapa lembaga kenegaraan seperti "Majelis Permusyawaratan Rakyat," "Dewan Perwakilan Rakyat," atau "Mahkamag Agung" juga menunjukkan diterimanya nomenklatur Islam.

Selain itu ucapan "assalamu'alaikum" secara tidak resmi sudah menjadi ucapan "salam nasional." Hal ini dalam pengertian bahwa para pejabat tinggi negara, termasuk Presiden, menteri-menteri kabinet, pejabat-pejabat senior, memulai pidato resmi mereka dengan ucapan salam itu. Meskipun mungkin tidak membawa konsekuensikonsekuensi lebih Jauh yang substansial sifatnya, bagaimanapun gerakan "kultural" ini memperlihatkan langkah penting yang menunjukkan akomodasi cultural negara terhadap Islam. ${ }^{22}$

Islam politik yang berlangsung dewasa ini telah menemukan sebuah format baru. Ciri-cirinya yang utama, yang mencakup (1) landasan teologis, (2) tujuan, dan (3) pendekatan Islam politik, dipandang sama dan sebangun dengan konstruk negara kesatuan nasional Indonesia.

22Bahtiar Effendy, Islam dan Negara: Transformasi Gagasan dan Praktik PolitikIslam di Indonesia, 
Sejauh negara, baik secara ideologis maupun politis, berjalan di atas sebuah sistem nilai yang tidak bertentangan dengan ajaran-ajaran Islam, maka cukup bagi politisi Muslim menyatakan loyalitas dan dukungan mereka terhadap negara.

Sudah sangat jelas bahwa Islam politik tidak lagi mengispirasikan pembentukan sebuah negara Islam. Melainkan, berdasarkan pemahaman mereka terhadap ajaran-ajaran Islam maupun corak sosiologis masyarakat Indonesia yang sangat heterogen, mereka berkiprah dalam rangka membangun pembangunan sebuah system sosial-politik yang mencerminkan, atau sejalan sengan prinsip-prinsip umum nilai-niai politik Islam, termasuk keadilan, musyawarah, egalitarianisme dan partisipasi." 23

\section{Hubungan Agama danNegara}

Persoalan hubungan agama dan negara di masa modern merupakan salah satu subjek penting, yang meski telah diperdebatkan para pemikir Islam sejak hampir seabad lalu hingga sekarang ini tetap belum terpecahkan secara tuntas. Hal ini dapat dilihat perdebatan yang terus berkembang. Fenomena yang mengedepan ini bisa jadi dikarenakan keniscayaan sebuah konsep negara dalam pergaulan hidup masyarakat di wilayah tertentu. Suatu negara diperlukan untuk mengatur kehidupan sosial secara bersamasama dan untuk mencapai cita-cita suatu masyarakat. Di sini otoritas politik memiliki urgensinya dan harus ada yang terwakilkan dalam bentuk institusi yang disebut negara. Berdasarkan realitas tersebut, di antara kaum muslimin merasa perlu untuk merumuskan konsep negara.

Para sosiolog teoretisi politik Islam merumuskan beberapa teori tentang hubungan agama dan negara. Teori-teori tersebut secara garis besar dibedakan menjadi tiga paradigma pemikiran yaitu paradigma integralistik, paradigma simbiotik, dan paradigma sekularistik.

Paradigma pertama menyatakan bahwa hubungan antara agama dan negara tidak dapat dipisahkan (integrated). Asumsinya ditegakkan di atas pemahaman bahwa Islam adalah satu agama sempurna yang mempunyai kelengkapan ajaran di semua segmen kehidupan manusia, termasuk di bidang praktik kenegaraan. Karenanya, umat Islam berkewajiban untuk melaksanakan sistem politik Islami sebagaimana telah dicontohkan oleh Nabi Muhammad dan empat al-Khulafa' al-Rasyidin. Pandangan ini menghendaki agar negara menjalankan dwifungsi secara bersamaan, yaitu fungsi lembaga politik dan keagamaan. Menurut paradigma ini, penyelenggaraan suatu pemerintahan tidak berdasarkan kedaulatan rakyat melainkan merujuk kepada kedaulatan ilahi, sebab penyandang kedaulatan paling hakiki adalah Tuhan. Pandangan ini mengilhami gerakan fundamentalisme.

23Bahtiar Effendy, Islam dan Negara: Transformasi Gagasan dan Praktik PolitikIslam di Indonesia, 
Paradigma kedua berpendirian bahwa agama dan negara berhubungan secara simbiotik, antara keduanya terjalin hubungan timbal-balik atau saling memerlukan. Dalam kerangka ini, agama memerlukan negara, karena dengan dukungan negara, agama dapat berkembang. Sebaliknya negara membutuhkan agama, karena agama menyediakan seperangkat nilai dan etika untuk menuntun perjalanan kehidupan bernegara. Paradigma ini berusaha keluar dari belenggu dua sisi pandangan yang berseberangan: integralistik dan sekularistik. Selanjutnya, paradigma ini melahirkan gerakan modernisme dan neomodernisme.

Paradigma ketiga merefleksikan pandangan sekularistik. Menurut paradigma ini, agama dan negara merupakan dua entitas yang berbeda, sehingga tidak dapat dikaitkan secara timbal-balik. Islam dimaknai menurut pengertian Barat yang berpendapat bahwa wilayah agama sebatas mengatur hubungan individu dan Tuhan. Sehingga mendasarkan agama kepada Islam atau upaya untuk melakukan determinasi Islam terhadap bentuk tertentu dari negara akan senantiasa disangkal.

Secara garis besar ada dua spektrum pemikiran politik Islam yang berbeda. Pada spektrum pertama, beranggapan bahwa Islam harus menjadi dasar negara, bahwa syariah harus diterima konstitusi negara, kedaulatan politik ada ditangan Tuhan, gagasan tentang negara bangsa bertentangan dengan konsep ummah yang tidak mengenal batas-batas politik kedaerahan.

Pada spektrum lain, berpendapat bahwa istilah negara tidak dapat ditemukan dalam al-Quran. Pendapat seperti ini juga mengakui bahwa AlQur'an mengandung nilai-nilai dan ajaran-ajaran yang bersifat etis mengenai aktivitas sosial dan politik umat Islam.Negara Islam tidak ada di dalam Al-Qur'an dan Sunnah Nabi, tetapi nilai-nilai dan prinsipprinsip bernegara terdapat dalam ajaran Islam.

\section{Formalistik Islam menuju ke subtantifis Islam dan sinergi}

Indonesia bukanlah sebuah negara Islam ataupun negara sekuler, melainkan sebuah negara religious, dalam arti bahwa negara memungkinkan dan membantu warganya untuk menjalankan kewajibankewajiban agama mereka.

Pernyataan diatas sangat sesuai dengan apa yang terjadi di negara ini, dengan terbentuknya kebijakan-kebijakan pemerintah yang sejalan dengan ajaran-ajaran agama Islam. Adanya kebijakan tersebut, negara telah membantu warganya dalam menjalankan kewajiban-kewajiban umat beragama. Dari perkembangan realitas tersebut, di era 1980-an dan 1990-an kemudian terjadi proses relaksasi politik antara Islam dan negara. Negara mulai menampakkan wajahnya yang "ramah" terhadap Islam dan kemudian bersedia mengembangkan akomodasi.

Proses perubahan wajah politik Islam di Indonesia, dari formalistiklegalistik menuju substansialistik. Sebuah istilah yang untuk 
menggambarkan proses perubahan ideologi politik Islam di Indonesia dari kehendak untuk memperjuangkan formalisme Islam dalam struktur negara, atau menjadikan Islam sebagai dasar negara, menuju pemaknaanpemaknaan substansial atas nilai-nilai Islam kaitannya dengan negara.

Dalam konteks ini Islam tidak lagi dipandang dalam struktur simboliknya, tetapi lebih ditangkap semangat nilainilai yang dibawanya dalam konteks prinsip-prinsip rahmatan li al-alamin, misalnya nilai keadilan (al-'adl), kesamaan (al-musawah) dan musyawarah (syura) untuk dikembangkan dalam tata kehidupan kenegaraan. Apa yang ingin diwujudkan bukanlah idealisme tentang berdirinya negara Islam, atau tegaknya ideologi Islam, tetapi masyarakat yang adil dan makmur. Islam dalam konteks ini dipandang sebagai sebangun dengan konstruk negara kesatuan nasional Indonesia. Tidak membutuhkan legalistik antara Islam dan negara, sejauh negara baik secara ideologis maupun politis berjalan di atas sistem nilai yang tidak bertentangan dengan ajaran dan nilai-nilai Islam.

Penerimaan terhadap konstruk kesatuan nasional negara Indonesia juga secara langsung dipengaruhi oleh beberapa faktor penting lainnya. Hal ini mencakup kenyataan-kenyataan bahwa (1) negara menjamin kebebasan bagi kaum Muslim untuk menerapkan ajaran-ajaran agama mereka; (2) mayoritas penduduk Indonesia adalah pemeluk agama Islam; (3) konstitusi negara tidak bertentangan dengan ajaran Islam, bahkan hingga tingkat tertentu justru mencerminkan, subtansi prinsip-prinsip Islam.

\section{Kesimpulan}

Islam sebagai agama tidak menentukan sistem pemerintahan tertentu bagi muslim. Berdasarkan pendapat tersebut maka termasuk kedalam aliran simbiotik, pada aliran simbiotik ini beberapa kalangan muslim berpendapat bahwa Islam tidak menemukan suatu pola yang baku tentang teori negara yang harus dijalankan ummah. Menurut aliran ini, bahkan istilah negara pun tidak dapat ditemukan dalam al-Quran. Indonesia bukanlah negara teokrasi (negara agama) maupun negara sekuler, hanya memperlihatkan pentingnya kewajiban negara untuk mengakomodasi kepentingan-kepentingan kaum muslim. Hubungan agama dan negara di Indonesia secara umum dapat digolongkan ke dalam 2 (dua) bagian, yakni hubungan yang bersifat antagonistik dan hubungan yang bersifat akomodatif. Indonesia bukanlah sebuah negara Islam ataupun negara sekuler, melainkan sebuah negara religious, dalam arti bahwa negara memungkinkan dan membantu warganya untuk menjalankan kewajibankewajiban agama mereka. 


\section{Referensi}

,Teologi Baru Politik Islam Pertautan Agama, Negara danDemokrasi, (Yogyakarta: Galang Press, 2001)

Ahmad Syafi'i Maarif, Islam dan Masalah Kenegaraan Studi tentang Percaturandalam Konstituante, (Jakarta: LP3ES, 1996)

Ali Abdul Raziq, Al-Islam wa Usul al-Ahkam, Mesir: 1925, dan telah diterjemahkan ke dalam bahasa Indonesia, Islam dan Dasar-Dasar Pemerintahan, (Yogyakarta: Jendela, 2000),

Bahtiar Effendy, Islam dan Negara di Indonesia (Jakarta: PT Temprin, 1995)

Dede Rosyada, et. al., Pendidikan Kewargaan (Civic Education): Demokrasi, HakAsasi Manusia dan Masyarakat Madani, (Jakarta: ICCE UIN Syarif Hidayatullah, 2000)

Dede Rosyada, Pendidikan Kewargaan (Civic Education): Demokrasi, HakAsasi Manusia dan Masyarakat Madani, (Jakarta: ICCE UIN Syarif Hidayatullah, 2000)

Deliar Noer, Gerakan Modern Islam di Indonesia 1900-1942,(Jakarta: LP3ES, 1996)

John L. Esposito, Islam and Politics, terj. H.M. Josoef Sou'yb, Islam dan Politik, (Jakarta: PT. Bulan Bintang, 2000)

Jubair Situmorang, Model Pemikiran dan Penelitian Politik Islam, (Bandung: Pustaka Setia, 2014)

M. Din Syamsudin, Usaha Pencarian Konsep Negara dalam Sejarah Pemikiran Politik Islam(Bandung: Pustaka Hidayah, Cet. ke-1, 1999)

M. Rusli Karim, Negara dan Peminggiran Islam Politik, (Yogyakarta: Tiara Wacana, 1999)

Muhammad Tahir Azhari, Negara Hukum : Suatu Study Tentang PrrinsipPrinsupnyaDilihat Dari Segi Hukum Isam, Implementasinya Pada Periode Negara Madinah dan Masa Kini, (Jakarta: Bulan Bintang, 2003)

Munawir Sjadzali, Islam dan Tatanegara: Ajaran Sejarah dan Pemikiran, edisi revisi (Jakarta: UI Press, 2003) 